\title{
METHOD DEVELOPMENT FOR THE ELEMENTAL ANALYSIS OF ORGANIC RICH SOIL SAMPLES BY MICROWAVE PLASMA ATOMIC EMISSION SPECTROMETRY
}

\author{
CSILLA NOÉMI TÓTH ${ }^{\mathrm{a}^{*}}$, SÁNDOR HARANGI ${ }^{\mathrm{b}}$, ANIKÓ KÁROLYIc, \\ ISTVÁN FÁBIÁN ${ }^{c}$, EDINA BARANYAl ${ }^{\mathrm{a}}$
}

\begin{abstract}
In this study, the method development is described for the multi elemental determination of organic rich soil reference material (BCR 700) by the new microwave plasma atomic emission spectrometry (MP-AES). Two sample preparation methods were compared (open vessel digestion on a hot plate and closed vessel microwave assisted digestion) for the BCR sample and EDTA extraction was carried out. The recoveries were tested by MPAES and inductively coupled plasma optical emission spectrometry (ICPOES) method to investigate whether the more cost-effective nitrogen supplied microwave plasma is appropriate for the elemental determination of digested organic rich soil samples. The BCR 700 sample was not certified for digestion methods yet similar sample pretreatment is present in the literature with which a good agreement was found. Our results also correlated with the values provided in the certification of the BCR 700 material for EDTA extraction. It was found that the microwave plasma is an effective and lowcost alternative of ICP-OES for soil analysis and with the convenient atmospheric digestion even the organic rich soil samples can be prepared prior to the elemental determination. However, the microwave assisted digestion is faster and easier to conduct. The limit of detection values of the measured elements by MP-AES are sufficiently low for the micro element determination of soils (Cd $70 \mu \mathrm{g} \mathrm{kg}^{-1}$, Cr $5 \mu \mathrm{g} \mathrm{kg}^{-1}$, Cu $25 \mu \mathrm{g} \mathrm{kg}^{-1}, \mathrm{Mn} 12.5 \mu \mathrm{g}$ $\mathrm{kg}^{-1}$, Ni $45 \mu \mathrm{g} \mathrm{kg}{ }^{-1}$, Pb $\left.220 \mu \mathrm{kg}^{-1}, \mathrm{Zn} 155 \mu \mathrm{kg}^{-1}\right)$.
\end{abstract}

Keywords: microwave plasma, inductively coupled plasma, atomic emission spectrometry, soil analysis, sample preparation

a University of Debrecen, Department of Inorganic and Analitycal Chemistry, Agilent Atomic Spectroscopy Partner Laboratory, Egyetem square 1. H-4032, Debrecen, Hungary

${ }^{b}$ University of Debrecen, Department of Ecology, P.O. Box 71, H-4010 Debrecen, Hungary

c University of Debrecen, Department of Inorganic and Analitycal Chemistry, Egyetem square 1. H-4032, Debrecen, Hungary

* Corresponding author: toth.csilla.noemi@science.unideb.hu 


\section{INTRODUCTION}

Atomic spectrometry provides several tools for elemental analysis [1-3]. The most widely applied technique is inductively coupled plasma optical emission spectrometry (ICP-OES), which is nowadays a routine method for the quantitative determination of elements from solutions [4]. Nearly together with the ICP, in the 1970s, the microwave excitation sources had been developed and tested [5, 6], which application possibilities were discussed in several papers so far [7-11]. The conventional MIP instruments operate on a lower electric capacity and gas flow compared to the ICPS, and their analytical performance is lower due to the lower thermal stability and matrix tolerance of the applied emission source [12]. For these disadvantages it did not became commercially available, however the development of stable MIP sources continuously stayed in the focus of researchers [7, 8, 13 -18].

The new method has already been applied for several purposes yet many fields of application is still open to the MP-AES technique [19]-[22].

Soil is one of the most important energy source of ecosystem, which quality must be monitored and preserved. The biological components are the most sensitive to the environmental change and tend to degrade upon human activity [19-24]. The chemical composition of soil is also an important parameter and can indicate pollution both from natural and anthropogenic origin. Several essential elements are present in soil which are vital for the terrestrial flora and fauna (such as $\mathrm{Co}, \mathrm{Cu}, \mathrm{Fe}, \mathrm{Mn}, \mathrm{Zn}$ ) however, above the threshold limit, they have a toxic effect [25-28]. There are also toxic elements which have no essential functions to living organisms (such as $\mathrm{Al}, \mathrm{Pb}, \mathrm{Cd}, \mathrm{Hg}$ ) therefore considered as pollutants in soils [19, 24, 29-33]. The elemental analysis of soil samples is of high importance to determine the amount of either essential trace metals or the quality and quantity of elemental contaminants. Atomic spectrometric methods are widely applied for this purpose and continuous development is required to meet the environmental principles.

The aim of this paper is to investigate the multi elemental determination of organic rich soil and the new method MP-AES was developed for trace element analysis by measuring a CRM soil (BCR 700) sample for $\mathrm{Cd}, \mathrm{Cr}$, $\mathrm{Cu}, \mathrm{Ni}, \mathrm{Pb}$ and $\mathrm{Zn}$.

\section{RESULTS AND DISCUSSION}

The organic rich BCR sample was pre-treated by open vessel digestion on a hot plate and closed vessel microwave assisted digestion with the mixture of nitric acid and hydrogen peroxide. The effectiveness of the digestion methods was investigated with internal standards of $\mathrm{Bi}$ (added prior to the sample preparation process) and $Y$ (added prior to the elemental analysis). 
Since the applied multi element stock solution originally contained $\mathrm{Bi}$, the experiment can be considered as a standard addition procedure. As seen in Figure 1 a good recovery was obtained, since the added Bi concentration was gained in a good agreement and with a low standard deviation.

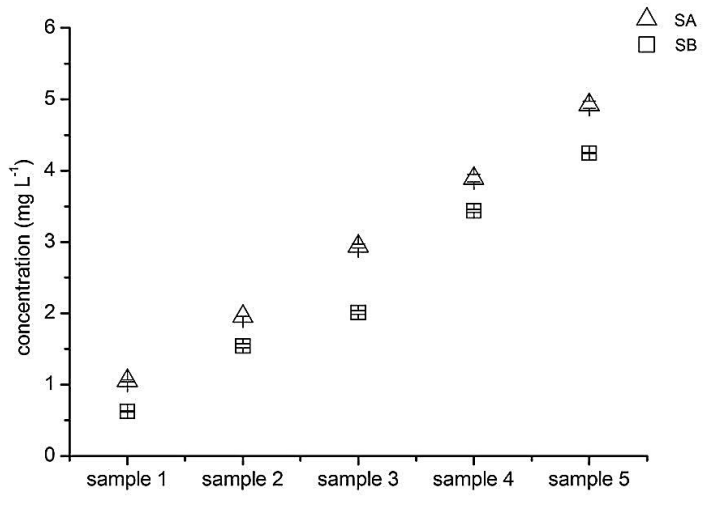

Figure 1. The Bi concentration of the digested SA (multi element stock solution + nitric acid + hydrogen peroxide) and SB (SA + BCR700 soil sample +

$\mathrm{Bi}$ internal standard $+\mathrm{Y}$ internal standard) $\left(\mathrm{mg} \mathrm{L}^{-1} \pm \mathrm{SD}, \mathrm{n}=3\right)$

The analysis results for $Y$ is indicated in Figure 2. It was observed that a $14.02 \%$ more than the originally added $Y$ concentration was found in the digested samples, respectively, while in the blank samples the expected value was found. It suggests that the reference material contained $Y$ however its level was under the limit of detection of the MP-AES method. Therefore, it was not detected from the soil samples before its addition.

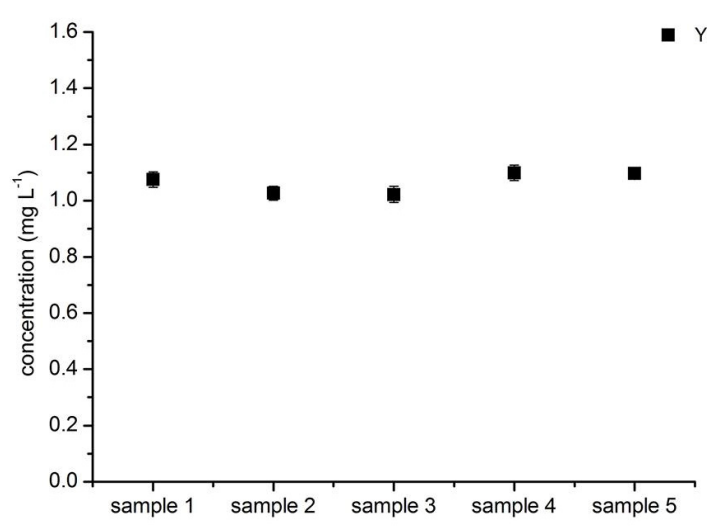

Figure 2. The $Y$ concentration of the digested SB sample (SA + BCR700 soil sample $+B i$ internal standard $+Y$ internal standard $)\left(m g ~ L^{-1} \pm S D, n=3\right)$ 
The two internal standards proved that no sample loss occurs during the open vessel sample preparation process. The optimization of the sample pre-treatment was continued with the comparison of the open vessel digestion on a hot plate and closed vessel microwave assisted digestion, with two different initial sample masses $(0.2 \mathrm{~g}$ and $0.5 \mathrm{~g})$. Figure 3 shows the MP-AES results for the measured elements ( $\mathrm{Cd}, \mathrm{Cr}, \mathrm{Cu}, \mathrm{Mn}, \mathrm{Ni}, \mathrm{Pb}$ and $\mathrm{Zn}$ ) of the BCR 700 sample in case of the two digestion techniques.

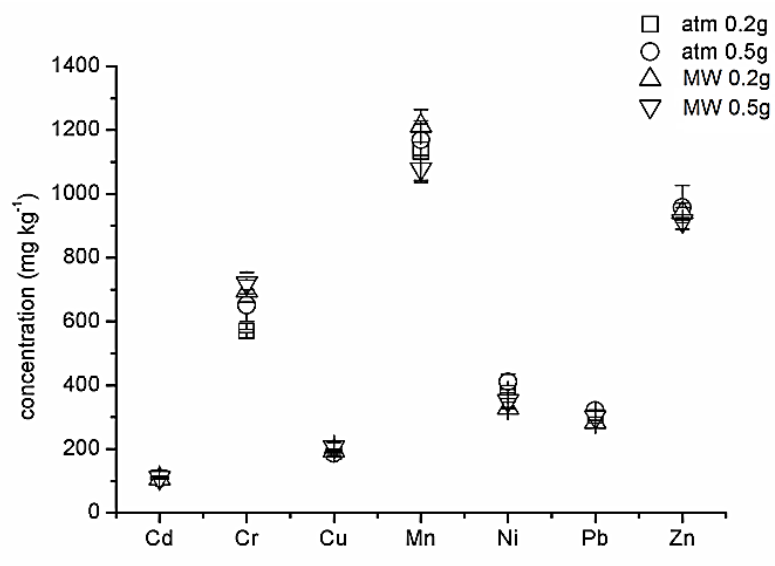

Figure 3. The elemental analysis results of soil samples (BCR700) prepared by open vessel $(\mathrm{atm})$ and microwave assisted $(\mathrm{MW})$ digestion with $0.2 \mathrm{~g}$ and $0.5 \mathrm{~g}$ of initial sample masses $\left(\mathrm{mg} \mathrm{kg}^{-1} \pm \mathrm{SD}, \mathrm{n}=3\right)$

The concentrations gained after both open vessel digestion on a hot plate and closed vessel microwave assisted digestion provided similar concentration results regardless the initial masses $(p>0.05)$. It indicates that both methods are appropriate for the elimination of the organic matter from the organic rich BCR 700 sample and 0.2 grams is enough to carry out the quantitative analysis. However, the microwave assisted method is faster and requires less attention during operation.

The measurement of $\mathrm{Cd}, \mathrm{Cr}, \mathrm{Cu}, \mathrm{Mn}, \mathrm{Ni}, \mathrm{Pb}$ and $\mathrm{Zn}$ was carried out by ICP-OES and MP-AES, respectively. Limit of detection (LOD) values were determined for the measured elements by both techniques and are compared in terms of the applied wavelengths in Table 1. We can conclude that the MP-AES method is sufficient regarding the LOD data for soil analysis. In some cases, similar LOD results were gained compared to ICPOES suggesting that the lower temperature plasma source is enough for the excitation of the measured elements. 
METHOD DEVELOPMENT FOR THE ELEMENTAL ANALYSIS OF ORGANIC RICH SOIL SAMPLES ...

Table 1. The limit of detection values together with the applied wavelengths for ICP-OES and MP-AES methods

\begin{tabular}{|c|c|c|c|c|c|c|}
\hline Element & $\begin{array}{l}\text { Wavelength } \\
(\mathrm{nm})\end{array}$ & $\begin{array}{c}\text { MP-AES } \\
\text { LOD } \\
\left(\mu g L^{-1}\right)\end{array}$ & $\begin{array}{c}\text { MP-AES } \\
\text { LOD } \\
\left(\mu \mathrm{g} \mathrm{kg}^{-1}\right)\end{array}$ & $\begin{array}{l}\text { Wavelength } \\
(\mathrm{nm})\end{array}$ & $\begin{array}{c}\text { ICP-OES } \\
\text { LOD } \\
\left(\mu \mathrm{g} \mathrm{L}^{-1}\right)\end{array}$ & $\begin{array}{c}\text { ICP-OES } \\
\text { LOD } \\
\left(\mu \mathrm{g} \mathrm{kg}^{-1}\right)\end{array}$ \\
\hline Cd & 228.802 & 1.4 & 70 & 228.802 & 0.04 & 2 \\
\hline $\mathrm{Cr}$ & 425.433 & 0.1 & 5.0 & 267.716 & 0.20 & 10 \\
\hline $\mathrm{Cu}$ & 324.754 & 0.5 & 25 & 324.754 & 0.15 & 7.5 \\
\hline$M n$ & 403.076 & 0.25 & 12.5 & 257.61 & 0.03 & 1.5 \\
\hline $\mathrm{Ni}$ & 352.454 & 0.9 & 45 & 231.604 & 0.70 & 35 \\
\hline $\mathrm{Pb}$ & 405.781 & 4.4 & 220 & 220.353 & 1.10 & 55 \\
\hline $\mathrm{Zn}$ & 213.857 & 3.1 & 155 & 213.857 & 0.10 & 5 \\
\hline
\end{tabular}

Table 2 indicates the detailed experimental results of BCR 700 analysis comparing ICP-OES and MP-AES data as well as the applied sample pretreatment techniques. The used organic rich reference material is only certified for elemental analysis after EDTA extraction, but Begum et al. (2012) studied its composition after wet digestion [38]. Thus, in the table concentration results gained by digestions are compared with literature data. A good correlation was found between the two atomic spectrometric methods and no significant difference occurred between them according to the statistical analysis. These results prove that the microwave plasma is suitable for the elemental analysis of organic rich soil samples providing a satisfactory multi elemental alternative to ICP-OES.

The excitation source of newly released MP-AES instrument is supported by nitrogen gas instead of argon which price is significantly lower. Also, a nitrogen generator can be applied producing nitrogen gas from air making the system even more cost-effective during operation. However, as found in this study, the emission line of $\mathrm{Zn}$ for example is in the ultraviolet range $(213.857 \mathrm{~nm})$ which requires the continuous gas purge of the optical system to avoid the absorption caused intensity decrease. The nitrogen generator of MP-AES cannot produce enough gas for purging thus an externally connected nitrogen gas cylinder is suggested to purge the optics.

In case of the EDTA extracted soil samples better recoveries were gained by ICP-OES compared to MP-AES (Table 3). Although both methods proved to be accurate we assume that the applied EDTA concentration was high and loaded the lower temperature microwave plasma thus further experiments are required to find the right concentration of the extraction solution that can be directly introduced to the microwave plasma without causing interferences. 
Table 2. The elemental analysis results of BCR 700 by MP-AES and ICP-OES after open vessel digestion on a hot plate and closed vessel microwave assisted digestion (n.d.: no data is available)

\begin{tabular}{c|ccccccccccc} 
Sample & \multicolumn{10}{c}{ Element $\left(\mathbf{m g ~ k g} \mathbf{~}^{-1}\right)$} \\
\hline $\begin{array}{c}\text { MP-AES c } \\
\text { (mg kg-1) }\end{array}$ & $\mathbf{C d}$ & $\mathbf{R S D} \%$ & $\mathbf{C u}$ & $\mathbf{R S D} \%$ & $\mathbf{N i}$ & $\mathbf{R S D} \%$ & $\mathbf{P b}$ & $\mathbf{R S D} \%$ & $\mathbf{Z n}$ & $\mathbf{R S D} \%$ \\
ATM_0.2g & $111 \pm 0.1$ & 0.08 & $192 \pm 4$ & 2.16 & $389 \pm 11$ & 2.79 & $305 \pm 15$ & 4.78 & $947 \pm 24$ & 2.53 \\
ATM_0.5g & $108 \pm 2$ & 1.65 & $186 \pm 4$ & 2.36 & $411 \pm 24$ & 5.83 & $321 \pm 2$ & 0.58 & $958 \pm 69$ & 7.17 \\
MW_0.2g & $105 \pm 0.8$ & 0.70 & $196 \pm 5$ & 2.57 & $328 \pm 2$ & 0.55 & $285 \pm 4$ & 1.46 & $941 \pm 16$ & 1.70 \\
MW_0.5g & $111 \pm 5$ & 4.79 & $207 \pm 14$ & 6.66 & $352 \pm 5$ & 1.47 & $300 \pm 0.6$ & 0.20 & $914 \pm 5$ & 0.50 \\
\hline ICP-OES c & & & & & & & & & & \\
(mg kg-1) & & & & & & & & & & \\
ATM_0.2g & $107 \pm 0.6$ & 0.57 & $158 \pm 4$ & 2.35 & $259 \pm 0.7$ & 0.27 & $233 \pm 0.3$ & 0.13 & $1342 \pm 3$ & 0.22 \\
ATM_0.5g & $104 \pm 1$ & 0.95 & $158 \pm 2$ & 1.05 & $299 \pm 4$ & 1.38 & $224 \pm 5$ & 2.14 & $1346 \pm 11$ & 0.79 \\
MW_0.2g & $89 \pm 1$ & 1.18 & $157 \pm 2$ & 1.07 & $329 \pm 10$ & 3.06 & $239 \pm 4$ & 1.68 & $1343 \pm 25$ & 1.86 \\
MW_0.5g & $93 \pm 0.4$ & 0.40 & $158 \pm 4$ & 2.51 & $221 \pm 7$ & 3.35 & $232 \pm 0.8$ & 0.35 & $1325 \pm 58$ & 4.39 \\
\hline Begum et al., & $132 \pm 2$ & n.d. & $169 \pm 4$ & n.d. & $373 \pm 6$ & n.d. & $288 \pm 3$ & n.d. & $1584 \pm 22$ & n.d. \\
2012 [34] & & & & & & & & & &
\end{tabular}

Table 3. The MP-AES and ICP-OES results of EDTA extracted BCR700 compared to the certified values (recoveries are expressed in percentage difference)

\begin{tabular}{cccccc} 
Element & $\begin{array}{c}\text { BCR 700 certified } \\
\text { values }\left(\mathbf{m g ~ k g}^{-1}\right)\end{array}$ & $\begin{array}{c}\text { ICP-OES } \\
\left(\mathbf{m g ~ k g}^{-1}\right)\end{array}$ & $\begin{array}{c}\text { Recovery } \\
(\%)\end{array}$ & $\begin{array}{c}\text { MP-AES } \\
\left(\mathbf{m g ~ k g}^{-1}\right)\end{array}$ & $\begin{array}{c}\text { Recovery } \\
(\%)\end{array}$ \\
\hline $\mathbf{C d}$ & $65.2 \pm 3.5$ & $67.2 \pm 1.5$ & 3.02 & $76 \pm 0.5$ & 16.4 \\
$\mathbf{C r}$ & $10.1 \pm 0.9$ & $27.8 \pm 0.5$ & 63.6 & $35.4 \pm 0.6$ & 250 \\
$\mathbf{C u}$ & $89.4 \pm 2.8$ & $85.7 \pm 0.7$ & -4.3 & $108.9 \pm 0.9$ & 21.8 \\
$\mathbf{N i}$ & $53.2 \pm 2.8$ & $65.4 \pm 0.4$ & 18.6 & $86.6 \pm 0.2$ & 62.7 \\
$\mathbf{P b}$ & $103 \pm 5$ & $110 \pm 2.1$ & 6.75 & $119 \pm 2.5$ & 15.1 \\
$\mathbf{Z n}$ & $510 \pm 17$ & $503 \pm 18$ & -1.31 & $577 \pm 19$ & 13.1 \\
\hline
\end{tabular}

\section{CONCLUSIONS}

The new microwave plasma atomic emission method was tested for the elemental analysis of organic rich soil (BCR 700) certified reference material. It was found that no significant difference occur between the open vessel digestion on a hot plate and closed vessel microwave assisted wet 
digestion. Both sample preparation techniques are suitable for the pre-treatment of organic rich soil samples, however the microwave digestion is faster and easier to conduct.

The MP-AES method proved to be appropriate for the determination of $\mathrm{Cd}, \mathrm{Cr}, \mathrm{Cu}, \mathrm{Mn}, \mathrm{Ni}, \mathrm{Pb}$ and $\mathrm{Zn}$ after the digestion procedure. However, the EDTA level present in the extracted soil samples loaded the microwave plasma and better recoveries were gained by ICP-OES. The EDTA content should be reduced or completely removed prior to the MP-AES determination to avoid the matrix effects or external oxygen should be applied among nitrogen to elevate the robustness of the excitation source.

\section{EXPERIMENTAL SECTION}

\section{Sample preparation}

The BCR 700 certified reference material of organic rich soil was homogenized then dried until constant weight at $105^{\circ} \mathrm{C}$ in drying cabinet.

For the open vessel digestion, on a hot plate, 0.5 grams of the dried sample was weighed on analytical balance (Precisa 240A) into glass beakers and was digested on an electric hot plate along with $4 \mathrm{ml} 65 \%(\mathrm{~m} / \mathrm{m})$ nitric acid (analytical grade VWR) and $0.50 \mathrm{ml}$ of $30 \%(\mathrm{~m} / \mathrm{m})$ hydrogen peroxide (reagent grade Scharlau). After the heating, samples were transferred without loss into volumetric flasks and filled up until $25 \mathrm{ml}$ with $0.1 \mathrm{M}$ nitric acid prepared in ultrapure water (MilliQ A10, Millipore). The sample pretreatment was carried out with a reduced, 0.2 grams of initial sample mass as well. The preparation was carried out in triplicate.

The closed vessel microwave assisted digestion was carried out in an ETHOS UP system from Milestone. Digestion parameters and the thermal program are indicated by Table 4 . The same amount of dried soil sample $(0.2 \mathrm{~g}$ and $0.5 \mathrm{~g}$ ) and chemicals were applied as well as the final volume of the gained solutions was $25 \mathrm{ml}$ - similarly to the atmospheric digestion process.

Table 4. Digestion parameters of the EHOS UP (Milestone)

\begin{tabular}{cccc}
\hline \multicolumn{4}{c}{ MW program "BCR 700" } \\
\hline $\mathrm{Nr}$ & $\mathrm{t}$ & $\mathrm{T} 1$ & $\mathrm{E}$ \\
1 & $0: 15: 00$ & $200^{\circ} \mathrm{C}$ & $1800 \mathrm{~W}$ \\
2 & $0: 20: 00$ & $200^{\circ} \mathrm{C}$ & $1800 \mathrm{~W}$ \\
\hline
\end{tabular}


In order to verify the digestion steps internal standards were used. Prior to the sample pretreatment a known concentration of Bi stock solution was applied since according to our preliminary measurements Bi was present under the limit of detection in the BCR material. Two sample series were prepared:

- SA - containing a multi element standard stock solution (Merck IV) nitric acid and hydrogen peroxide,

- SB - SA + BCR 700 and Bi.

The prepared 5 samples contained the multi element solution in an increasing order from $1 \mathrm{mg} \mathrm{L}^{-1}$ to $5 \mathrm{mg} \mathrm{L}^{-1}$. After the atmospheric digestion a known concentration $\left(1 \mathrm{mg} \mathrm{L}^{-1}\right)$ of $Y$ standard solution was also added to SB samples. The detailed compositions of the model samples are indicated in Table 5.

Table 5. The composition of the model samples, the volume and concentration of the applied internal standards and digestion chemicals

\begin{tabular}{|c|c|c|c|c|c|c|}
\hline SA & $\begin{array}{l}\text { multi element } \\
\text { standard } \\
1000 \mathrm{mg} \mathrm{L}^{-1}\end{array}$ & $\begin{array}{c}\text { BCR } \\
700(g)\end{array}$ & $\begin{array}{l}\mathrm{Bi} 100 \\
\mathrm{mg} \mathrm{L}^{-1}\end{array}$ & $\begin{array}{l}Y 100 \\
\mathrm{mg} \mathrm{L}^{-1}\end{array}$ & reagent & $\begin{array}{c}\text { final } \\
\text { volume } \\
\text { (ml) }\end{array}$ \\
\hline 1. atm & $0 \mu \mathrm{l}$ & - & - & - & $\begin{array}{l}4 \mathrm{ml} 65 \% \mathrm{HNO}_{3}+ \\
30 \% 0.5 \mathrm{ml} \mathrm{H}_{2} \mathrm{O}_{2}\end{array}$ & 25 \\
\hline 2. atm & $250 \mu \mathrm{l}$ & - & - & - & $\begin{array}{l}4 \mathrm{ml} 65 \% \mathrm{HNO}_{3}+ \\
30 \% 0.5 \mathrm{ml} \mathrm{H}_{2} \mathrm{O}_{2}\end{array}$ & 25 \\
\hline 3. atm & $500 \mu \mathrm{l}$ & - & - & - & $\begin{array}{l}4 \mathrm{ml} 65 \% \mathrm{HNO}_{3}+ \\
30 \% 0.5 \mathrm{ml} \mathrm{H}_{2} \mathrm{O}_{2}\end{array}$ & 25 \\
\hline 4. atm & $750 \mu \mathrm{l}$ & - & - & - & $\begin{array}{l}4 \mathrm{ml} 65 \% \mathrm{HNO}_{3}+ \\
30 \% 0.5 \mathrm{ml} \mathrm{H}_{2} \mathrm{O}_{2}\end{array}$ & 25 \\
\hline 5. atm & $1000 \mu \mathrm{l}$ & - & - & - & $\begin{array}{l}4 \mathrm{ml} 65 \% \mathrm{HNO}_{3}+ \\
30 \% 0.5 \mathrm{ml} \mathrm{H}_{2} \mathrm{O}_{2}\end{array}$ & 25 \\
\hline 6. atm & $1250 \mu \mathrm{l}$ & - & - & - & $\begin{array}{l}4 \mathrm{ml} 65 \% \mathrm{HNO}_{3}+ \\
30 \% 0.5 \mathrm{ml} \mathrm{H}_{2} \mathrm{O}_{2}\end{array}$ & 25 \\
\hline \multicolumn{7}{|l|}{ SB } \\
\hline 7. atm & $0 \mu \mathrm{l}$ & 0.2000 & $250 \mu \mathrm{l}$ & $250 \mu \mathrm{l}$ & $\begin{array}{l}4 \mathrm{ml} 65 \% \mathrm{HNO}_{3}+ \\
30 \% 0.5 \mathrm{ml} \mathrm{H}_{2} \mathrm{O}_{2}\end{array}$ & 25 \\
\hline 8. atm & $250 \mu \mathrm{l}$ & 0.2000 & $250 \mu \mathrm{l}$ & $250 \mu \mathrm{l}$ & $\begin{array}{c}4 \mathrm{ml} 65 \% \mathrm{HNO}_{3}+ \\
30 \% 0.5 \mathrm{ml} \mathrm{H}_{2} \mathrm{O}_{2}\end{array}$ & 25 \\
\hline 9. atm & $500 \mu \mathrm{l}$ & 0.2000 & $250 \mu \mathrm{l}$ & $250 \mu \mathrm{l}$ & $\begin{array}{c}4 \mathrm{ml} 65 \% \mathrm{HNO}_{3}+ \\
30 \% 0.5 \mathrm{ml} \mathrm{H}_{2} \mathrm{O}_{2}\end{array}$ & 25 \\
\hline 10. atm & $750 \mu \mathrm{l}$ & 0.2000 & $250 \mu \mathrm{l}$ & $250 \mu \mathrm{l}$ & $\begin{array}{l}4 \mathrm{ml} 65 \% \mathrm{HNO}_{3}+ \\
30 \% 0.5 \mathrm{ml} \mathrm{H}_{2} \mathrm{O}_{2}\end{array}$ & 25 \\
\hline 11. atm & $1000 \mu \mathrm{l}$ & 0.2000 & $250 \mu \mathrm{l}$ & $250 \mu \mathrm{l}$ & $\begin{array}{l}4 \mathrm{ml} 65 \% \mathrm{HNO}_{3}+ \\
30 \% 0.5 \mathrm{ml} \mathrm{H}_{2} \mathrm{O}_{2}\end{array}$ & 25 \\
\hline 12. atm & $1250 \mu \mathrm{l}$ & 0.2000 & $250 \mu \mathrm{l}$ & $250 \mu \mathrm{l}$ & $\begin{array}{c}4 \mathrm{ml} 65 \% \mathrm{HNO}_{3}+ \\
30 \% 0.5 \mathrm{ml} \mathrm{H}_{2} \mathrm{O}_{2}\end{array}$ & 25 \\
\hline
\end{tabular}


The BCR 700 material is certified for EDTA extraction. On analytical balance 5 grams of dried BCR sample was measured and $50 \mathrm{ml}$ of $0.05 \mathrm{M}$ EDTA (Merck) was added to it in Erlenmeyer flasks. Ultrasound bath (Transsonic 460/H) was used for one hour. Then extracted soil samples were filtered (Schleicher \& Schuell $5951 / 21.4 \mu \mathrm{m}$ ) into $50 \mathrm{ml}$ volumetric flasks. In Table 6 the conditions of sample preparation applied for BCR 700 reference material are summarized.

Table 6. The sample preparation parameters of the organic rich soil (BCR 700) reference material

\begin{tabular}{|c|c|c|c|}
\hline digestion & BCR 700 (g) & reagent & final volume (ml) \\
\hline atm. & 0.5000 & $\begin{array}{l}4 \mathrm{ml} 65 \% \mathrm{HNO}_{3}+ \\
30 \% 0.5 \mathrm{ml} \mathrm{H}_{2} \mathrm{O}_{2}\end{array}$ & 25 \\
\hline MW & 0.5000 & $\begin{array}{l}5 \mathrm{ml} 65 \% \mathrm{HNO}_{3}+ \\
30 \% 0.5 \mathrm{ml} \mathrm{H}_{2} \mathrm{O}_{2}\end{array}$ & 25 \\
\hline atm. & 0.2000 & $\begin{array}{l}4 \mathrm{ml} 65 \% \mathrm{HNO}_{3}+ \\
30 \% 0.5 \mathrm{ml} \mathrm{H}_{2} \mathrm{O}_{2}\end{array}$ & 25 \\
\hline MW & 0.2000 & $\begin{array}{l}5 \mathrm{ml} 65 \% \mathrm{HNO}_{3}+ \\
30 \% 0.5 \mathrm{ml} \mathrm{H}_{2} \mathrm{O}_{2}\end{array}$ & 25 \\
\hline extraction & 5.0000 & 0.05M EDTA & 50 \\
\hline
\end{tabular}

\section{Instrumentation}

The $\mathrm{BCR}$ soil samples were determined for $\mathrm{Cd}, \mathrm{Cr}, \mathrm{Cu}, \mathrm{Ni}, \mathrm{Pb}$ and $\mathrm{Zn}$ by inductively coupled plasma optical emission spectrometry (ICP-OES 5100 Agilent Technologies) and microwave plasma atomic emission spectrometry (MP-AES 4200, Agilent Technologies) after the open vessel digestion on a hot plate and closed vessel microwave assisted digestion as well as the EDTA extraction. A 5 points calibration was applied (Merck ICP IV) and the purity of chemicals were verified by measuring blank samples.

The first commercially available microwave plasma atomic emission spectrometer (MP-AES) was released in 2011, which applies a robust excitation source for stable and continuous measurements. The magnetron generates electromagnetic wavelengths at $2.5 \mathrm{GHz}$ and the magnetic field is focused axially around the torch. Plasma is supplied with nitrogen produced by a generator from air which makes the technique the most cost-effective one in the field of atomic spectrometry. The excitation source has a lower temperature (approx. 5000-6000 K) to that of the inductively coupled ones (approx. 8000$10000 \mathrm{~K}$ ) and the interferences occurring in the plasma is less studied so far. 
Measuring parameters together with the applied wavelengths are indicated in Table 7. The MP-AES software provides less parameters to be adjusted by the user since the microwave plasma provides robust in a narrower range compared to the inductively coupled one. Thus, values of nitrogen flow are fixed however the nebulizer pressure can be adjusted per the measured elements.

The viewing position in case of both instruments was zero. In MP-AES automatic background correction was applied while in ICP-OES measurements fitted correction was used - both offered by the Agilent Spectra software. Solutions were measured in analyte type except the standards of calibration. Double pass spray chamber and sea spray nebulizer was used for sample introduction along with SPS3 (Agilent Technologies) autosampler.

Table 7. The measurement parameters of MP-AES and ICP-OES

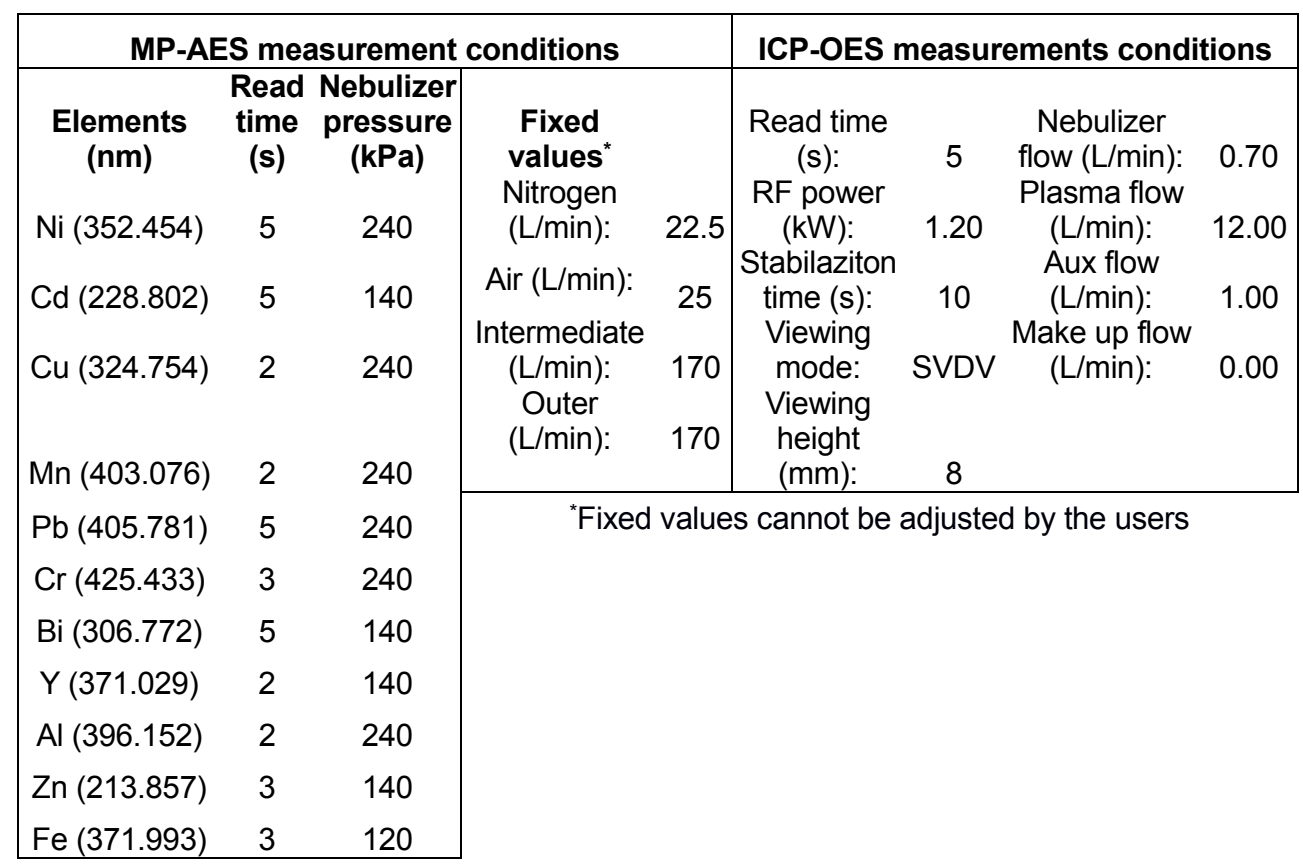

\section{Evaluation of data}

Statistical analysis was applied to compare the elemental analytical results gained by ICP-OES and MP-AES method. General Linear Model (ANOVA) was used (SPSS IBM 22) where the homogeneity of the groups was tested by Levene's test and the significant differences were evaluated by Tukey's Multiple Comparison test. 


\section{ACKNOWLEDGMENTS}

The research was supported by the EU and co-financed by the European Regional Development Fund under the project GINOP-2.3.2-152016-00008. We would like to highly acknowledge Agilent Technologies (Novo-Lab Ltd.) for providing the MP-AES 4200 and ICP-OES 5100 instruments and Milestone (Novo-Lab Ltd.) for the ETHOS UP microwave digestion system.

\section{REFERENCES}

1. B. Welz and M. Sperling, Eds., Atomic Absorption Spectrometry. Weinheim, Germany: Wiley-VCH Verlag GmbH, 1998.

2. B. Welz, H. Becker-Ross, S. Florek, and U. Heitmann, High-Resolution Continuum Source AAS: The Better Way to Do Atomic Absorption Spectrometry. Weinheim, FRG: Wiley-VCH Verlag GmbH \& Co. KGaA, 2005.

3. R. Cornelis, Ed., Handbook of elemental speciation: techniques and methodology. Chichester, West Sussex, England; Hoboken, NJ: Wiley, 2003.

4. E. Frahm, G.F. Monnier, N.A. Jelinski, E.P. Fleming, B.L. Barber, and J.B. Lambon, Journal of Archaeological Science, 2016, 75,115.

5. H.P. Broida and M.W. Chapman, Analytical Chemistry, 1938, 30, 2049.

6. N.S. Ham and A. Walsh, Spectrochimica Acta, 1958,12, 88.

7. J.A.C. Broekaert and U. Engel, "Microwave-Induced Plasma Systems in Atomic Spectroscopy," in Encyclopedia of Analytical Chemistry, R.A. Meyers, Ed. Chichester, UK: John Wiley \& Sons, Ltd, 2000.

8. J.A.C. Broekaert and V. Siemens, Spectrochimica Acta Part B Atomic Spectroscopy, 2004, 59, 1823.

9. S. Greenfield, H.M. Mcgeachin, and P.B. Smith, Talanta,1975, 22, 3.

10. P.C. Uden, American Chemical Society, and American Chemical Society, Eds., Element-specific chromatographic detection by atomic emission spectroscopy. Washington, DC: American Chemical Society, 1992.

11. A.T. Zander and G.M. Hieftje, Applied Spectroscopy, 1981, 35, 357.

12. K.J. Jankowski and E. Reszke, Microwave induced plasma analytical spectrometry. Cambridge: Royal Society of Chemistry, 2010.

13. D. Beauchemin, J.C. Yves Le Blanc, G.R. Peters, and A.T. Persaud, Analytical Chemistry, 1994, 66, 462.

14. J.A.C. Broekaert and E. Hywel Evans, "Atomic Spectroscopy," in Ullmann's Encyclopedia of Industrial Chemistry, Wiley-VCH Verlag GmbH \& Co. KGaA, Ed. Weinheim, Germany: Wiley-VCH Verlag GmbH \& Co. KGaA, 2003. 
15. J.A.C. Broekaert, "Plasma optical emission and mass spectrometry," in Determination of Trace Elements, Z.B. Alfassi, Ed. Weinheim, Germany: Wiley-VCH Verlag GmbH, 1994, pp. 191-251.

16. J.A.C. Broekaert, N. Bings, C. Prokisch, and M. Seelig, Spectrochimica Acta Part B Atomic Spectroscopy, 1998, 53, 331.

17. C. Yang, Z. Zhuang, Y. Tu, P. Yang, and X. Wang, "Spectrochimica Acta Part B Atomic Spectroscopy, 1998, 53, 1427.

18. U. Engel, A. M. Bilgiç, O. Haase, E. Voges, and J.A. Broekaert, Analytical Chemistry, 2000, 72, 193.

19. N. Ozbek and S. Akman, LWT - Food Science Technology, 2015, 61, 532.

20. N. Ozbek and S. Akman, Food Chemistry, 2016, 192, 295.

21. N. Ozbek and S. Akman, Food Chemistry, 2016, 200, 245.

22. Y. Zhao et al., Spectrochimica Acta Part B Atomic Spectroscopy, 2015, 112, 6.

23. Y. Lu, F. Zhu, J. Chen, H. Gan, and Y. Guo, Environmental Monitoring and Assessment, 2007, 134, 429.

24. J.W. Doran and Soil Science Society of America, Eds., Defining soil quality for a sustainable environment: proceedings of a symposium sponsored by Divisions S-3, S-6, and S-2 of the Soil Science Society of America, Division A5 of the American Society of Agronomy, and the North Central Region Committee on Soil Organic Matter (NCR-59) in Minneapolis, MN, 4-5 November 1992. Madison, Wis: SSSA : American Society of Agronomy, 1994.

25. C. Trasar-Cepeda, C. Leirs, F. Gil-Sotres, and S. Seoane, Biology and Fertility of Soils, 1997, 26, 100.

26. G. Várallyay, Cereal Research Communication, 2007, 35, 1277.

27. G. Várallyay, Agrokém. És Talajt., 2006, 55, 9.

28. G.D. Bending, C. Putland, F. Rayns, Biology and Fertility of Soils, 2000, 31, 78.

29. Z. Györi and J. Prokisch, Journal of Agricultural and Food Chem., 1999, 47, 2751.

30. M.A. Elbagermi, H.G.M. Edwards, and A.I. Alajtal, International Journal of Analytical Chemistry, 2013, 1.

31. E. Simon et al., Ecological Indicators, 2016, 60, 258.

32. G. Tyler, Forest Ecology and Management, 2005, 206, 167.

33. T.-B. Chen et al., Chemosphere, 2005, 60, 542.

34. R. Ballesta, P. Bueno, J. Rubi, R. Giménez, Open Geosciences, 2010, 2, 441.

35. I. Massas, C. Ehaliotis, S. Gerontidis, and E. Sarris, Environmental Monitoring and Assessment, 2009, 151,105.

36. O. Morton-Bermea, E. Hernández-Álvarez, G. González-Hernández, F. Romero, R. Lozano, and L. E. Beramendi-Orosco, Journal of Geochemical Exploration, 2009, 101, 218.

37. M. Imperato, P. Adamo, D. Naimo, M. Arienzo, D. Stanzione, and P. Violante, Environmental Pollution, 2003, 124, 247.

38. Z.A. Begum, I.M.M. Rahman, Y. Tate, H. Sawai, T. Maki, and H. Hasegawa, Chemosphere, 2012, 87, 1161. 